Вісник ЛНУ імені Тараса Шевченка № 6 (337), 2020

УДК 930.2+719

DOI 10.12958/2227-2844-2020-6(337)-54-63

\title{
Присяжнюк Олексій Миколайович,
}

доцент кафедри всесвітньої історії та методології науки Д3 „Південноукраїнський національний педагогічний університет імені К. Д. Ушинського”,

м. Одеса, Україна.

a_pank@ukr.net

https://orcid.org/0000-0003-3727-5350

\section{„КОРОЛІВСЬКА КОМІСІЯ ПАМ'ЯТНИКІВ ТА ЛАНДШАФТІВ" ЯК ГАРАНТ КУЛЬТУРНОЇ СПАДЩИНИ БЕЛЬГІЇ}

„Королівська комісія пам'ятників та ландшафтів” була однією 3 перших європейських інституцій, що виникла у XIX столітті та заклала основи систематичної охорони культурної спадщини. Крім цього, інтерес до „своєї” історії та „своїх” пам'ятників, в основному релігійних, організація їх охорони i розвиток реставрації як самостійного архітектурного руху були визначені внутрішньополітичними проблемами Бельгії, пов'язаними 3 радикальною зміною соціально-політичного вигляду самого суспільства (Сухий, 2005, с. 214-215).

Джерельну базі статті склала фундаментальна праця Ежена Віолле-ле-Дюка, яка містить його роздуми про архітектуру, принципи реставрації середньовічних пам'яток, міркування про велич середньовічної готики (Виолле-ле-Дюк, 2012). Також нами було використане зібрання королівських постанов, розпоряджень та законів, що стосуються повноважень Королівської комісії (Les fabriques d'église, 2012). Докладний звіт щодо діяльності Королівської комісії пам'ятників та ландшафтів здійснений у грунтовній статистичній праці П. Гіліссена (Gilissen, 1999).

Метою статті $є$ необхідність проаналізувати процес оформлення інституцій охорони пам'яток Бельгії на протязі XIX-XX століть.

Лише 3 поширенням інтелектуального руху, що охоплює Свропу за часи романтизму, ми знаходимо перші сліди ефективних заходів на користь захисту того, що тоді ще не називалося культурною спадщиною. Віктор Гюго стверджує, що першим у 1825 р. оголосив „війну знищувачам” і в передмові до „Собору Паризької богоматері” 1830 р. проголошує: „Збережемо старовинні пам'ятники, вселимо в Націю любов до національної архітектори" (Кривонос, 2017). Офіційні кола липневої монархії за наказом міністра Ф. Гізо швидко почули це гасло Гюго, тому у 1834 році король Луї-Філіп призначає Проспера Меріме на 
посаду генерального інспектора пам'ятників історії. Ця нова адміністрація у Франції була завершена створенням Комісії історичних пам'яток у 1837 році (Присяжнюк, 2019).

Зі свого боку, дуже молода держава Бельгія дуже рано усвідомила важливість цього питання. Фактично королівським указом від 7 січня 1835 року король Леопольд I створив Королівську комісію пам'ятників у складі дев'яти членів:

граф Франсуа Робіано, сенатор, голова Комісії,

граф Жорж де Бофорт,

Франсуа-Жозеф Наве, художник-неокласик,

Тільман-Франсуа Сюї, архітектор,

Моріс Роже, головний інженер мостів і доріг,

Луї Роелан, архітектор у Генті,

П’єр Бруно Бурла, архітектор в Антверпені,

Бруно Ренар, архітектор в Турне,

Олександр Декрейн, архітектор (Gilissen, 1999, p. 151).

Нова комісія несе відповідальність за надання рекомендацій міністру внутрішніх справ щодо „ремонту, який потребують пам'ятники країни за своєю давниною, спогадами, які вони викликають, або їх важливістю у історії мистецтва [...] та про плани, пов'язані з будівниитвом та ремонтом будівель, згаданих у статті 2 указу від 2 серпня 1824 р. (тобто споруд культу) та інших громадських будівель" (Gilissen, 1999, p. 152).

На перший погляд можна здивуватися, побачивши як уряд нової держави Бельгії, народженої ще дуже нещодавно, яка все ще є дуже невизначеною (країна ще офіційно воює з Голландією!), надає пріоритет у своій установчій діяльності громадських структур створенню дорадчого органу в питанні, яке вважається мистецьким, до того ж не є життєво важливим для держави.

Здійснюючи наш аналіз, ми повинні розглядати указ про створення Королівської комісії пам'ятників та ландшафтів як політичний у, як не дивно, найблагороднішому розумінні цього терміну. Дійсно, події 1830 року стали початком справжньої національної революції, i будь-яка дія, що сприяла зміцненню бельгійського національного характеру серед населення, частина якого все ще залишалася проголландською, негайно викликала відповідь нового уряду i, перш за все, монарха Леопольда I. У цьому відношенні важливо, що створення Королівської комісії було здійснене за кілька років до прийняття муніципальних та провінційних законів, які стали опорою бельгійського демократичного та децентралізованого режиму. Саме в цьому контексті піднесення патріотичного руху необхідно вивчити інтерес влади до історичної спадщини та процесу створення Королівської комісії.

Крім того, і цей другий момент має вирішальне ідеологічне значення, слід зауважити, що одне $з$ повноважень Королівської комісії 
базується на королівському указі від 16 серпня 1824 р. „про те, щзо церковні установи та адміністрації не можуть домовлятися щзодо об'єктів, опіку над якими прямо не покладено на них діючими законами, положеннями та постановами" (Les fabriques, 2012). Це регулятивне положення, прийняте протестантом Віллемом I Оранським-Нассау, королем Нідерландів, на шкоду ієрархії католицької церкви, головним чином бельгійської, створювало абсолютну опіку уряду над будь-яким будівництвом або перетворенням церкви, чи навіть над вилученням чи відчуженням будь-якого предмету мистецтва, що зберігається в церкві.

У конституційній Бельгії після 1831 року, де миряни-ліберали та ультра-католики наділялися абсолютно новою і все ще неміцною владою, доручити комісії експертів завдання вивчити справи та радити міністру було способом відновлення рівноваги.

Перша зміна структури Королівської комісії відбулася згідно королівського указу від 31 травня 1860 р. про створення комітетів відповідних членів на провінційному рівні під головуванням губернаторів. Ці нові члени комітетів ,збирають інформацію та надають пропозиціі”, які від них вимагає Комісія, та „контролюють, за необхідності, виконання роботи, яку вона затвердила". Вони також можуть, офіційно звернути увагу уряду чи комісії на заходи, які вони вважають корисними для збереження пам'ятників чи творів мистецтва (Gilissen, 1999, p. 154).

Через кілька місяців королівським указом від 23 лютого 1861 року, який стосувався загальної інвентаризації творів мистецтва та античності, Королівській комісії було доручено здійснити загальну інвентаризацію артефактів мистецтва та античності, що належать публічним установам, збереження яких важливе для історії мистецтва та національної археології. Королівська комісія повинна скласти план цієї інвентаризації, який буде поданий на затвердження міністра внутрішніх справ.

30 червня 1862 року королівським указом було встановлено Порядок роботи Королівської комісії. Порядок дуже детальний, текст складається $3 \quad 12$ глав та 74 статей, пов'язаних із нормальним функціонуванням Комісії. В ньому обговорена процедура подання пропозицій щодо роботи, охарактеризовані обов'язки офіційних та добровільних членів, правила засідань, бюджет, плата за відвідування тощо. Також оговорене створення „Об'єднаного комітету творів мистецтва", що повинен складатися 3 трьох представників Королівської комісії та трьох уповноважених, призначених Королівською бельгійською академією. Цей текст також розповідає нам, що в той час студенти-архітектори були передані в розпорядження Президента та секретаріату Комісії для виконання планів, креслень чи інших робіт. Ці студенти-архітектори зобов'язані були перебувати у розпорядження Комісії протягом усього періоду сесій та виконувати роботу, яку 
секретар призначив їм від імені Комісії. У разі надзвичайної ситуації вони повинні надавати допомогу працівникам Секретаріату та робити письмовий звіт щоразу, коли їм доручається якась місія.

У Бельгії - країні, де в архітектурному плані еклектичний та особливо неоготичний стилі є всюдисущими, на політику збереження та реставрації, яку проводила Королівська комісія в той час, безумовно, сильно впливали теорії, розроблені Е. Віолле-ле-Дюком. Нагадаємо, що у своєму „Словнику французької архітектури 3 XI до XVI ст.”, опублікованому у 1856 році, він визначив реставрацію так: „Реставрувати будівлю не означає підновляти іiі, ремонтувати або перебудовувати; це значить - відновлювати ії завершений стан, якого вона могло й не мати ніколи до теперішнього часу" (Виолле-ле-Дюк, 2012, с. 118).

Це був час великих піонерів, архітекторів-реставраторів та мистецтвознавців, деякі з яких були членами Королівської комісії, які залишили ім'я в історії збереження монументальної спадщини в Бельгії, наприклад Огюст Ван Аш (1826-1907), Жан-Шарль Делсо (1821-1893), Еміль Вьєрсе-Годін (1824-1891), Жюль Брюнфо (1852-1942), Едмонд Жамар (1853-1929), шевальє Ежен Соль де Моральме (1853-1934), Поль Жаспар (1859-1945), канонік Ежен Пюї-Сант (1860-1934), Фернан Лое (1864-1932) та багато інших.

Після прийняття закону від 12 серпня 1911 р. про збереження краси ландшафтів, який накладає на будь-якого власника шахт, кар'єрів чи на будь-якого концесіонера громадських робіт зобов'язання відновити зовнішній вигляд грунту чи ділянки після закінчення роботи, в Королівській комісії з'явилась секція ландшафтів, затверджена королівським указом від 29 травня 1912 року. 3 цього часу вона отримала свою сучасну назву Королівської комісії пам'ятників та ландшафтів.

Уряд, „з естетичного інтересу, щуоб захистити природну красу країни, ї̈ ділянки та мальовничі пейзажі, залишити їх у безпеці та запобігти деградації” та ,з наукового інтересу, щоб гарантувати збереження деяких особливо иікавих місиевостей, аутентичного трунту, його геологічних особливостей, рослин та місцевих тварин рідкісних чи характерних видів, а також залишків доісторії", накладає нові обов'язки на членів Королівської комісії:

- надати пропозиції „щодо робочих проектів, які можуть загрожувати існуванню або заподіяти шкоду иілісності найцікавіших ландшафтів країни";

- висловити обгрунтовані думки „щодо попередніх робіт ma проектів, щзо стосуються дорожніх робіт, які в містах чи інших місиях прямо чи опосередковано торкаються естетичних питань" (Gilissen, 1999, p. 155).

Одним із перших проявів впливу нової секції Комісії на владу було прийняття закону від 26 березня 1914 року про збереження в якості пам'ятки поля битви при Ватерлоо, який діє й сьогодні. 
Члени Королівської комісії розробили внутрішню класифікацію пам'яток, a також ландшафтів та місць, найбільш цікавих для Королівства. Ця класифікація, неофіційна та призначена суто для органів державної влади, була структурована у класи відповідно до важливості для інтересів королівства:

1) монументальні культові споруди; 2) громадські будівлі; 3) приватні будівлі; 4) ландшафти; 5) дерева.

Королівська комісія повідомила уряд та зацікавлені державні органи про своє рішення класифікувати майно, про яке йде мова, i регулярно публікувати перелік класифікованих нею об'єктів нерухомості. Останній опублікований такий список датований 1926 роком і включає понад 3000 об'єктів нерухомості на всій території Королівства.

Ця практика, зрештою, ще не маючи правової основи, призвела до поступового ствердження концепції класифікації, яка вперше була затверджена у Законі від 7 серпня 1931 р. про збереження пам'яток та ландшафтів.

Закон 1931 року став кульмінацією майже столітніх зусиль Королівської комісії. Завдяки ньому Бельгія придбала сучасний юридичний арсенал, що дозволяє реально проводити політику щодо охорони спадщини. 3 цього часу Комісія стала найважливішим органом для розгляду запитів на роботу 3 класифікованими об'єктами та офіційним джерелом запитів для класифікаційних пропозицій.

Крім того, на підтвердження королівського указу від 23 лютого 1861 року, який стосувався загальної інвентаризації творів мистецтва та старовини, Закон 1931 р. доручає Комісії проводити інвентаризацію ,рухомих предметів, щзо належать державі, провіниії, комуні та громадській установі, збереження яких представляе національний інтерес з художньої точки зору. [...] Ці інвентаризації подаються відповідним адміністраціям”. Королівська комісія „може в будь-який час направити одного зі своїх уповноважених зібрати інвентаризовані об'єкти та здійснити інвентаризацію колекиї”' (Gilissen, 1999, p. 156). Слід звернути увагу на той факт, що останнє положення ніколи не було скасовано і тому теоретично може бути застосовне до сьогодення.

Згаданий вище „Об'єднаний комітет творів мистецтва”, який працює в Королівській комісії за участі представників Королівської академії Бельгії з метою вивчення роботи відновлення картин та творів мистецтва, що належать до громадських будівель, працював не дуже вдало. У щорічному звіті Королівської комісії за 1953 фінансовий рік зазначено такий пасаж: „Інвентаризація художніх творів, передбачена законом від 7 серпня 1931 р., не відбулася [...] Ми можемо тільки пошкодувати щодо відчуження та втрати об'єктів, які підлягають інвентаризації, через відсутність достатнього контролю, яких завжди слід побоюватися. Необхідно щоб уряд надав у розпорядження Комісії 
засоби, необхідні для заповнення иієї серйозної прогалини в намій начіональній програмі охорони спадщини" (Gilissen, 1999, p. 156).

У 1957/58 рр. було видано „Довідник важливих культурних пам'яток", згідно якому пам'ятки були розподілені так: архітектура, живопис, скульптура, національна археологія, зарубіжна археологія, національна історія, етнографія, музика (органологія). Крім того, Королівська комісія опублікувала у Бюлетені 1959 року „Перелік пам'яток та творів мистецтва" для районів Антверпена та Льєжа, в якому перелічено „культові споруди, громадські та приватні будівлі, твори мистецтва, щзо є пам'ятками мистецтвва та архітектури".

Починаючи 31861 р. Королівська комісія вела дуже активну публікаційну діяльність Результати іiі роботи (пропозиції, протоколи загальних зборів) i те, що можна назвати ефемеридами Комісії (призначення, смерті, відставки) регулярно повідомлялися у „Віснику Королівської комісії пам'яток та ландшафтів". Починаючи 31949 р. наукові статті та щорічні доповіді Комісії публікувалися на двох національних мовах поряд. Таке двомовне видання існувало до 1969 року, коли відбувся розкол Королівської комісії між „фламандцями” та „франкофонами”. В цілому з 1958 року система охорони пам'яток історії та культурної спадщини Бельгії була розділена між регіонами. 31989 року повноваження щодо охорони пам'яток передані федеральним регіонам: Брюсельському, Фламандському та Валлонському та Німецькомовному співтовариству.

Також Комісія сприяла публікації монографій, найбільш яскравою 3 яких стало дослідження Саймона Брігода „Релігійна архітектура на південному заході Бельгії”, видана у 1950 році.

За структурою Комісія складалася 3 членів-волонтерів, обраних відповідно до їх досвіду в галузі охорони спадщини (архітектура, історія мистецтв, археологія, історія, музика, географія, геологія, ботаніка, зоологія, геоморфологія). На чолі Королівської комісії з 1835 по 1958 рр. послідовно перебували: граф Франсуа Робіано, граф Жорж де Бофорт, месьє Франсуа Веллен, шевальє Роже Ла Гассе де Ло, який головував в Комісії більше 50 років та граф Едмон Картон де Віар - п'ять президентів за 123 роки.

Едмон Картон де Віар був призначений членом Королівської комісії, коли в червні 1912 року була створена секція ландшафтів, став президентом у травні 1937 року і залишалася на посаді до грудня 1958 року. Значно випереджаючи свій час, він одразу позиціонував себе одним iз перших захисників концепції охорона природи. На загальних зборах Королівської комісії 27 листопада 1934 року він виступив із повідомленням „Промисловість та охорона природи”: „У зусиллях, які Королівська комісія з пам'ятників та ландшафтів продовжує зберігати природну красу нашої краӥни, вона стикається з багатьма перешкодами. Дурний смак і вандалізм - ие вороги, з якими вона бореться безжально, 
проти яких боротьба відносно проста, бо иіль чітко визначена. Але $\epsilon$ більш серйозна перешкода: ие те, шо тут ситуаиія ускладнюється тим, щчо дуже добре розуміючи економічні потреби краӥни, Королівська комісія не може бути байдужою до неї, коли вона прагне зберегти наші найкращі ландшафти. У такій індустріалізованій країні, як наша, яка стільки зобов'язана промисловості, вже потрібно певна зухвалість говорити про права природи, протилежні правам промисловості. [...] Я хотів би продемонструвати всім виробникам та іншим членів бельгійської громади, щуо повага до Природи є важливою" (Les fabriques d'église, 2012, p. 187).

Таким чином, Королівська комісія пам'ятників та ландшафтів Бельгії була однією з перших європейських інституцій, що виникла у XIX столітті та заклала основи систематичної охорони культурної спадщини. Фактично вона була створена указом короля Леопольда I 7 січня 1835 року. Створення Королівської комісії було здійснене за кілька років до прийняття муніципальних та провінційних законів, які стали опорою бельгійського демократичного та децентралізованого режиму. У 1860 році відбулися зміни структури Королівської комісії - були створені комітети на провінційному рівні під головуванням губернаторів. На комітети був покладений збір інформації на місцях та контроль за виконанням робіт щодо збереження пам'ятників чи творів мистецтва. Королівській комісії було доручено здійснити загальну інвентаризацію артефактів мистецтва та античності, що належать публічним установам, збереження яких важливе для історії мистецтва та національної археології. Після прийняття закону від 1911 р. про збереження краси ландшафтів в Королівській комісії з'явилась секція ландшафтів, затверджена королівським указом від 29 травня 1912 року. 3 цього часу вона отримала свою сучасну назву Королівської комісії пам'ятників та ландшафтів.

Члени Королівської комісії розробили внутрішню класифікацію пам'яток, а також ландшафтів та місць, найбільш цікавих для Королівства. Ця практика призвела до поступового ствердження концепції класифікації, яка вперше була затверджена у Законі від 7 серпня 1931 р. про збереження пам'яток та ландшафтів. Закон 1931 року став кульмінацією майже столітніх зусиль Королівської комісії. Завдяки ньому Бельгія придбала сучасний юридичний арсенал, що дозволяє реально проводити політику щодо охорони спадщини.

\section{Список використаної літератури}

1. Сухий О. М. Історія Бельгії. Львів: ПІРАМІДА, 2005. 260 с. 2. Виолле-ле-Дюк Э. Э. Энциклопедия готической архитектуры. М.: ЭКСМО, Наше слово, 2012. 512 с. 3. Les fabriques d'église / sous la coordination de Michel Davagle, Jean-François Husson et Jean-François Debuisson; Alphonse Borras, Michel Davagle, Hervé Debroux et al. Liège: Edipro, 2012. Vol. 1. 204 p. 4. Gilissen P. La Commission royale des 
Monuments et des Sites... des origines à 1958. Les Cahiers de l'urbanisme. 1999. №25-26. Р. 150-157. 5. Кривонос Р. А. Бельгія. Краӥни світу $i$ Україна: енциклопедія: в 5 т. Т. 1. Київ: Видавництво „Фенікс”, 2017. С. 236-264. 6. Присяжнюк О. М. Осягнення національного минулого та оформлення основ охорони пам'яток у Франції. Науковий вісник Міжнародного гуманітарного університету. Сер.: Історія. Філософія. Політологія. 2019. №17. С. 30-34.

\section{References}

1. Sukhyi, O. M. (2005). Istoriia Belhii [History of Belgium]. Lviv: PIRAMIDA [in Ukrainian]. 2. Violle-le-Dyuk, E. E. (2012). Yentsiklopediya goticheskoy arkhitektury [Encyclopedia of Gothic Architecture]. Moskow: YEKSMO, Nashe slovo [in Russian]. 3. Les fabriques d'église. (2012). (Vol. 1). Liège: Edipro [in French]. 4. Gilissen, P. (1999). La Commission royale des Monuments et des Sites... des origines à 1958. Les Cahiers de l'urbanisme, 25-26, 150-157 [in French]. 5. Kryvonos, R. A. (2017). Belhiia. Krainy svitu i Ukraina: entsyklopediia [Belgium. Countries of the world and Ukraine: encyclopedia]. (Vol. 1), (pp. 236-264). Kyiv: Vydavnytstvo „Feniks” [in Ukrainian]. 6. Prysiazhniuk, O. M. (2019). Osiahnennia natsionalnoho mynuloho ta oformlennia osnov okhorony pamiatok u Frantsii [Understanding the national past and drawing up the basics of monument protection in France]. Naukovyi visnyk Mizhnarodnoho humanitarnoho universytetu. Ser.: Istoriia. Filosofiia. Politolohiia, 17, 30-34 [in Ukrainian].

Присяжнюк О. М. „Королівська комісія пам'ятників та ландшафтів" як гарант культурної спадщини Бельгії

„Королівська комісія пам'ятників та ландшафтів” Бельгії була однією з перших європейських інституцій, що виникла у XIX столітті та заклала основи систематичної охорони культурної спадщини. Фактично вона була створена указом короля Леопольда I 7 січня 1835 року. Створення Королівської комісії було здійснене за кілька років до прийняття муніципальних та провінційних законів, які стали опорою бельгійського демократичного та децентралізованого режиму. У 1860 році відбулися зміни структури Королівської комісії - були створені комітети на провінційному рівні під головуванням губернаторів. На комітети був покладений збір інформації на місцях та контроль за виконанням робіт щодо збереження пам'ятників чи творів мистецтва. Королівській комісії було доручено здійснити загальну інвентаризацію артефактів мистецтва та античності, що належать публічним установам, збереження яких важливе для історії мистецтва та національної археології. Після прийняття закону від 1911 р. про збереження краси ландшафтів в Королівській комісії з'явилась секція ландшафтів, затверджена королівським указом від 29 травня 1912 року. 3 цього часу вона отримала свою сучасну назву Королівської комісії пам'ятників та ландшафтів. 
Члени Королівської комісії розробили внутрішню класифікацію пам'яток, a також ландшафтів та місць, найбільш цікавих для Королівства. Ця практика призвела до поступового ствердження концепції класифікації, яка вперше була затверджена у Законі від 7 серпня 1931 р. про збереження пам'яток та ландшафтів. Закон 1931 року став кульмінацією майже столітніх зусиль Королівської комісії. Завдяки ньому Бельгія придбала сучасний юридичний арсенал, що дозволяє реально проводити політику щодо охорони спадщини. 3 цього часу Комісія стала найважливішим органом для розгляду запитів на роботу 3 класифікованими об'єктами та офіційним джерелом запитів для класифікаційних пропозицій.

Ключові слова: національна історія, національне минуле, музеєзнавство, історична пам'ятка, охорона пам'яток, законодавча база, спадщина.

Присяжнюк А. Н. „Королевская комиссия памятников и ландшафтов" как гарант культурного наследия Бельгии

„Королевская комиссия памятников и ландшафтов” Бельгии была одной из первых европейских институций, возникших в XIX веке и заложившей основы систематической охраны культурного наследия. Фактически она была создана указом короля Леопольда I 7 января 1835 г. Создание Королевской комиссии было осуществлено за несколько лет до принятия муниципальных и провинциальных законов, ставших опорой бельгийского демократического и децентрализованного режима. В 1860 году произошли изменения структуры Королевской комиссии - были созданы комитеты на провинциальном уровне под председательством губернаторов. На комитеты был возложен сбор информации на местах и контроль за выполнением работ по сохранению памятников или произведений искусства. Королевской комиссии было поручено осуществить общую инвентаризацию артефактов искусства и античности, принадлежащих публичным учреждениям, сохранение которых важно для истории искусства и национальной археологии. После принятия закона 1911 г. о сохранении красоты ландшафтов в Королевской комиссии появилась секция ландшафтов, утверждённая королевским указом от 29 мая 1912 года. С этого времени она получила свое современное название Королевской комиссии памятников и ландшафтов.

Члены Королевской комиссии разработали внутреннюю классификацию памятников, а также ландшафтов и мест, наиболее интересных для Королевства. Эта практика привела к утверждению концепции классификации, которая впервые была утверждена в Законе от 7 августа 1931 года о сохранении памятников и ландшафтов. Закон 1931 г. стал кульминацией почти столетних усилий Королевской комиссии. Благодаря ему Бельгия приобрела современный юридический арсенал, который позволяет ей реально проводить политику по охране 
наследия. С этого времени Комиссия стала важнейшим органом для рассмотрения запросов на работу с классифицированными объектами и официальным источником запросов для классификационных предложений.

Ключевые слова: национальная история, национальное прошлое, музееведение, историческая достопримечательность, охрана памятников, законодательная база, наследие.

Prysiazhniuk O. M. „Royal Commission on Monuments and Landscapes" as a guarantor of the cultural heritage of Belgium

The „Royal Commission on Monuments and Landscapes” of Belgium was one of the first European institutions to emerge in the 19th century and lay the foundations for the systematic protection of cultural heritage. In fact, it was created by decree of King Leopold I on January 7, 1835. The Royal Commission was set up a few years before the adoption of municipal and provincial laws, which became the backbone of the Belgian democratic and decentralized regime. In 1860, the structure of the Royal Commission changed - committees were established at the provincial level under the chairmanship of the governors. The committees were tasked with gathering information on the ground and overseeing the preservation of monuments or works of art. The Royal Commission was commissioned to make a general inventory of artifacts of art and antiquity belonging to public institutions, the preservation of which is important for the history of art and national archeology. Following the enactment of the Landscape Beauty Act of 1911, a section of landscapes appeared in the Royal Commission, approved by a royal decree of May 29, 1912. Since then, it has received its current name, the Royal Commission on Monuments and Landscapes.

Members of the Royal Commission have developed an internal classification of monuments, as well as landscapes and places of most interest to the Kingdom. This practice led to the gradual adoption of the concept of classification, which was first approved in the Law of 7 August 1931 on the Preservation of Monuments and Landscapes. The law of 1931 was the culmination of almost a century of efforts by the Royal Commission. Thanks to him, Belgium has acquired a modern legal arsenal that allows for a real policy on heritage protection. Since then, the Commission has become the most important body for dealing with requests for work with classified objects and the official source of requests for classification proposals.

Key words: national history, national past, museum studies, historical monument, monument protection, legislative base, heritage.

Стаття надійшла до редакції 09.11.2020 р. Прийнято до друку 13.11.2020 р.

Рецензент - д. і. н., проф. Набока О. В. 